\title{
Idea zrównoważonego rozwoju w kształceniu studentów kierunków nauczycielskich
}

\begin{abstract}
STRESZCZENIE
Współczesna neoliberalna rzeczywistość o jednoznacznych regułach zachowań narzuca twardą grę społeczną. Jednocześnie powszechnie panujący mainstreamowy „nakaz” domagający się rozmywania międzyludzkich relacji, podważania znaczeń i aprobaty wszelkich postaw bez możliwości ich oceny, doprowadził do całkowitego rozchwiania człowieka i jego świata w wymiarze społecznym, kulturowym, przyrodniczym i polityczno-gospodarczym. Potrzeba powrotu do równowagi staje się coraz bardziej czytelna. Droga do życia zrównoważonego wymaga dobrze, powszechnie i odpowiedzialnie prowadzonej edukacji. Pierwszym poważnym projektem w tym kierunku była Dekada Edukacji na rzecz Zrównoważonego Rozwoju. Dziś podejmuje się aktywności w ramach Globalnego Programu Działań. Aby wielki plan wprowadzania w życie idei zrównoważonego rozwoju mógł być przeprowadzony, potrzebni są dobrze przygotowani nauczyciele. Ich kształcenie staje się wyzwaniem o wymiarze ogólnoświatowym. Niestety obowiązki i oczekiwania stawiane nauczycielom znacząco hamują proces zmiany. Diagnoza pedeutologicznych tendencji i problemów w skali globalnej jest ważnym elementem przygotowania się do pracy z polskimi nauczycielami. W artykule ukazano możliwe do zastosowania (wykorzystując obecną podstawę programową do szkół podstawowych i średnich) sposoby rozbudzania świadomości i wprowadzania młodych ludzi w zagadnienia zrównoważonego rozwoju. Jednym z nich jest narzędzie - Projekt $X$, dzięki któremu studenci Uniwersytetu Łódzkiego - przyszli nauczyciele - uczą
\end{abstract}

1 Aneta Rogalska-Marasińska, Wydział Nauk o Wychowaniu, Uniwersytet Łódzki, Polska, anetarm@yahoo.com. 
się, jak myśleć w sposób zrównoważony oraz łączyć problematykę i treści z różnych przedmiotów szkolnych w jeden spójny i wychowawczo pożądany edukacyjny przekaz.

\section{Słowa kluczowe:}

edukacja na rzecz zrównoważonego rozwoju, kształcenie i doskonalenie nauczycieli akademickich i szkolnych, problemy z implementacją idei zrównoważenia w przygotowaniu i rozwoju zawodowym nauczycieli, Projekt $X$

\section{ABSTRACT}

Contemporary neoliberal reality with clear and unambiguous rules of actions imposes tough social inter-dependences and obligations. At the same time, commonly present mainstream tendency to weaken interpersonal relations, to doubt in senses and meanings, and to accept each behaviour without the possibility to formulate personal attitude towards it, has led to total mess in human life. An unbalanced man hardly manages to exist in all devastated dimensions of his world: social, cultural, environmental and economical. The need to turn back and to reach the sustainable level of life becomes more and more clear. The route to sustainability needs ambitious, common and responsible education. The Decade of Education for Sustainable Development was the first global project. Now we should undertake activities presented in Global Action Plan. To make that immense plan become real we need properly and thoroughly prepared school teachers and academics. Pre-service and in-service teacher development becomes a global issue. Contemporary vocational obligations and expectations formulated towards that group of professionals considerably inhibit the process of change. That is why, the diagnosis of global pedeutological problems and tendencies is one of the most important steps for preparing a better plan to work with Polish teachers. The paper presents possible ways to work with students - future teachers - to develop sustainable awareness and attitudes, derived from proper knowledge and skills. Project $X$ is one of the most interesting and inspiring educational tools. Basing on Polish primary and secondary curriculum, students of the University of Lodz learn how to think in sustainable manner, and how to join knowledge and skills from various schools subjects to build a holistic educational message.

\section{Keywords:}

education for sustainable development, teacher education and vocational training of university and school teachers, problems with implementation of sustainability in pre- and in-service teacher education, Project $X$ 


\section{WSTĘP}

Współczesna rzeczywistość zwykle określana jest jako trudna, pełna wyzwań i niepokojów lub niejasności. Niestety współtworzący ją człowiek - jako jednostka i jako członek różnorodnych grup i społeczności - ma, jak na razie, zbyt mały wpływ na przebiegające procesy i dokonujące się przeobrażenia. Za kluczowe tendencje lub zaakceptowane zmiany odpowiadają bowiem decydenci, których priorytety i wybory zasadniczo wynikają z ich partykularnych interesów, wykluczając dobro powszechne.

Taka utrzymująca się przez ostatnie dekady tendencja doprowadziła do katastrofalnego stanu wszystkich podstawowych środowisk życia człowieka. Według koncepcji zrównoważonego rozwoju są nimi: przyroda, kultura, społeczeństwo i gospodarka (Rogalska-Marasińska, 2017). Ludność, a szczególnie jej globalno-mainstreamowa (Martel, 2011) część, zagubiła się w dążeniu do egoistycznie interpretowanego sukcesu i jednostkowo pożądanego zysku. Eksponowana dziś przewaga materialna nad drugim człowiekiem - postrzeganym jako przeciwnik, rywal, konkurent, a nawet „obiekt do eliminacji” - ma świadczyć o całkowitej i w pełni uzasadnionej wyższości tego pierwszego. I choć wydawałoby się, że neoliberalna narracja i praktyka gry społeczno-ekonomicznej i konsumpcyjnej w pełni sprzyja takiemu porządkowi, to - jak się okazuje - doprowadzając do coraz większych dysproporcji międzyludzkich, międzykulturowych czy międzykontynentalnych ${ }^{2}$, rozbudza i wzmaga różne typy sprzeciwu - od debat i protestów po akty przemocy i zamachy terrorystyczne.

Dla milionów mieszkańców globu świat stał się „porozszarpywany”, niespójny i niezrozumiały. Dominują zachowania graniczne, wynikające z tendencji do spolaryzowanego, schematycznego, a często - stereotypowego postrzegania faktów. Język pogardy, relatywizm w „mierzeniu się” ze światem zewnętrznym i płynny charakter autorefleksji nad jakością indywidualnych wyborów i decyzji oraz nad kondycją własnej osobowości bezwzględnie manipulują człowiekiem. Traktują go przedmiotowo, tzn. systematycznie i planowo go „urabiają”, „przerabiają”, aby w końcu „porzucić” jako zasób, który być może przyda się w procesie kolejnego „recyclingu”. Koncepcje (neo)behawiorystyczne ponownie postrzega się jako pożądane i skuteczne w sterowaniu ludźmi. W związku z tym coraz powszechniej

2 Jak podaje Frédéric Martel, Amerykanie ze swym przemysłem entertainmentu: show-biznesem, mainstreamowymi filmami i muzycznym przebojami nie „zapuszczają się” do Afryki, gdyż kontynent ten jest „,niedochodowy”, „dla Amerykanów nie jest dość bogaty”, „ponieważ Amerykanie nic z niego nie rozumieją” (2011, s. 421). 
dochodzi do implementacji tychże ujęć w obszarze nowych mediów i technologii. Stosuje się je np. wobec użytkowników portali społecznościowych (Friesen, 2018).

Myśląc w perspektywie humanistycznej o przyszłości człowieka, nasuwają się więc pytania o charakter i drogi jego teraźniejszego kształcenia. Jak rozwijać indywidualną wrażliwość połączoną z rozumnym odbiorem i oceną świata? Jak pogłębiać potrzebę upominania się o piękno (w jego najdrobniejszych szczegółach i w całości) w życiu jednostek i w interakcjach międzyludzkich oraz w środowisku przyrodniczym i kulturowym? Jak rozwijać estetyczne i moralne współzależności w wymiarze społeczno-gospodarczym i politycznym? Jak uczyć dostrzegać różnorodne rodzaje nieprawidłowości, aby następnie skutecznie (np. wykorzystując obywatelskie możliwości negocjacji) im się sprzeciwiać i przeciwdziałać? Jak dochodzić własnych i jednocześnie wspólnych - ludzkich praw? To pytania-wyzwania, nad którymi dziś należy się pochylać, by wypracowywać drogi na rzecz zasadniczej zmiany funkcjonowania człowieka. Bowiem wiele na to wskazuje, że dociera on do granicy swojej egzystencji, której przekroczenie wiązać się będzie z katastrofą, a nawet zagładą ludzkości lub w „najlepszym” razie jej diametralną zmianą, deformacją albo totalną transformacją. To, co powstanie, będzie już zapewne jakimś innym wariantem „życia”. Zmodyfikowany świat będą wypełniały formy człekopodobne, ludzkie zastępniki lub cyborgi (Klichowski, 2014).

Zrównoważony rozwój zakłada współzależność wszystkich elementów świata życia człowieka w każdym z czterech głównych środowisk jego funkcjonowania. Świat kultury symbolicznej, materialnej i niematerialnej wyrasta na gruncie świata przyrody (ożywionej i nieożywionej). Ich współzależność przeniknięta jest tkanką wzorów życia społecznego, które wypracowało sposoby komunikacji międzyludzkiej i wymiany handlowej. Niestety ostatnie dziesięciolecia ukazują ogrom zniszczeń, których dokonał człowiek we wszystkich głównych obszarach swojego funkcjonowania. Zdewastowane i wyjałowione środowisko przyrodnicze, zaburzone relacje społeczne, odarta z systemu wartości i głębi kultura oraz bezwzględna, nastawiona na szybki zysk, a gardząca wszelkimi innymi dobrami - przede wszystkim samym człowiekiem - gospodarka to „poziom życia”, który „osiągnął” współczesny człowiek. Jest to stan totalnej dysharmonii i niezrównoważenia. Aby ponownie dać szansę człowiekowi na jego humanistyczny rozwój, czyli godny wzrost, w którym obecne i przyszłe pokolenia będą miały możliwość zaspakajać swoje potrzeby i realizować marzenia, niezbędne jest wejście na drogę odpowiedzialnej odbudowy świata poprzez rozwój zrównoważony. Drogowskazem dla tej nowej idei jest interpretacja samego pojęcia „zrównoważony” (ang. sustainable), utożsamianego z (prze)trwaniem, podtrzymywaniem, pielęgnacją i wsparciem. To także dążenie do harmonii, współpracy, rozwijanie szacunku 
wobec siebie samego, drugiego człowieka i innych istot, to budowanie solidarności społecznej i zaufania dającego szansę na bezpieczne i szczęśliwe życie. Osobiście taką interpretację koncepcji zrównoważonego rozwoju łączę z wizją Federica Mayora, który zaproponował implementację „umów”, umożliwiających odwrót od dysharmonii, w której ludzkość niemalże całkowicie się zatraciła. Są to: nowa umowa społeczna, umowa ekologiczna, umowa kulturowa i umowa etyczna (Mayor, Bind, 2001). Etyczne podstawy dla budowania sprawiedliwego, zrównoważonego i bezpiecznego społeczeństwa globalnego wyznacza też Karta Ziemi, która kluczowe kwestie określa już językiem i celów, reguł dyspozycji (Karta Ziemi). Aby ideały zrównoważenia można było skutecznie wprowadzać w życie, należało podjąć edukację na rzecz zrównoważonego rozwoju. Jej realizacja znacząco przyspieszyła z początkiem XXI w. (Rogalska-Marasińska, 2017).

\section{ZAŁOŻENIA EDUKACJI NA RZECZ ZRÓWNOWAŻONEGO ROZWOJU NA LATA 2015-2030 W PERSPEKTYWIE PRZYGOTOWANIA PRZYSZtYCH I OBECNYCH NAUCZYCIELI}

W 2014 r. zakończyła się Dekada Edukacji na rzecz Zrównoważonego Rozwoju. Jej zamknięcie miało miejsce podczas Światowej Konferencji UNESCO w Aichi-Nagoya w Japonii, zatytułowanej Learning Today for a Sustainable Future. Efektem tego spotkania były dwa dokumenty: deklaracja Aichi-Nagoya Declaration on Education for Sustainable Development (2015) oraz raport końcowy Shaping the future we want (2014). W deklaracji wyrażono przekonanie o potencjale tkwiącym w koncepcji i praktyce edukacji na rzecz zrównoważonego rozwoju. Wspomaga bowiem krytyczne, problemowe i systemowe myślenie, zachęca do poszukiwania kreatywnych rozwiązań, wspiera wysiłek na rzecz współpracy, a także rozwija umiejętności podejmowania odpowiedzialnych decyzji w sytuacjach nieznanych, które coraz częściej mają uwarunkowania lokalne i zarazem są globalnie współzależne. W raporcie Shaping the future we want wyrażono przekonanie, że w wielu obszarach życia człowieka udało się wprowadzić zrównoważone rozwiązania, szczególnie na poziomie społeczności lokalnych. Wiele szkół, uczelni wyższych, organizacji pozarządowych i firm prywatnych przystąpiło do poznawania i podjęło próby praktycznej realizacji zaleceń zrównoważonego rozwoju (Shaping the future we want, 2014; Review of the implementation, 2015; Śliwerski, 2015a).

Mimo pozytywnych zmian uznano, że wielu kwestii nie udało się właściwie rozwiązać. Pozostały też zadania, z którymi zupełnie wtedy jeszcze się nie zmie- 
rzono (Review of Targets, 2015) ${ }^{3}$. Dlatego podczas tej samej konferencji w Aichi-Nagoya zainicjowano nowy plan edukacyjny o nazwie Post-2015 GAP - Global Action Programme (tłum. Globalny Program Działań) (Global Action Programme on Education for Sustainable Development, 2015). Przyjęto, że przede wszystkim należy zapewnić uczącym się „,edukację dobrej jakości”“, która opierać się będzie na odpowiednio przygotowanych nauczycielach i na wzbogaconych o tematykę zrównoważenia programach nauczania. Dzięki takiemu wykształceniu młodzież będzie mogła podejmować pracę w „zielonych zawodach” lub w obszarach w dalszym ciągu oczekujących na powrót zrównoważonych decyzji i działań. Będzie też mogła przedstawiać własne pomysły rozwiązań - zgodnie z ideą harmonii, zrównoważenia i odpowiedzialności za wspólne dobro - pojawiających się nieznanych dotąd problemów i trudnych kwestii.

W tej sytuacji celem głównym Globalnego Programu Działań stało się założenie: „generować i pomnażać działania we wszystkich obszarach i na wszystkich etapach kształcenia, aby przyspieszać postęp na rzecz zrównoważonego rozwoju” (Review of the implementation, 2015, s. 14). Z niego wyprowadzono dwa cele pośrednie:

1. Przekształcić edukację, a w szczególności proces uczenia się, tak aby każdy miał szanse na zdobycie wiedzy, rozwinięcie umiejętności oraz przyswojenie wartości i postaw, które umożliwią mu aktywne włączenie się w zrównoważony rozwój;

2. Wzmocnić procesy uczenia się, które promują edukację na rzecz zrównoważonego rozwoju we wszystkich formach kształcenia, programach nauczania i aktywnościach poza-formalnych i nieformalnych.

Dokonano określenia pięciu priorytetowych obszarów działań, które powinny umożliwić podniesienie poziomu edukacji na rzecz zrównoważonego rozwoju. Są to:

1. Sprzyjająca polityka oświatowa - należy włączyć edukację na rzecz zrównoważonego rozwoju do głównego nurtu kształcenia;

2. Przekształcanie środowiska nauczania i uczenia się - kształcenie na wszystkich poziomach i we wszystkich formach (edukacja formalna, poza-

3 Z Milenijnych Celów Rozwoju dobrze udało się zrealizować tylko 29\%, 54\% wymagało dużego zaangażowania w ich prawidłowe wypełnienie, a 17\% kwestii oczekiwało na jakiekolwiek podjęcie.

4 „Edukacja dobrej jakości” lub „Jakościowa edukacja” to określenia nawiązujące do tytułu czwartego celu z zestawu 17 Celów Zrównoważonego Rozwoju (ang. Sustainable Development Goals) ogłoszonego przez UNESCO i przyjętego do realizacji na lata 2015-2030. 
-formalna i nieformalna) powinno prezentować holistyczne podejście do zrównoważonego rozwoju;

3. Rozwijanie potencjału nauczycieli i edukatorów - należy zwiększyć zakres kształcenia studentów przygotowujących się do roli nauczycieli, jak i pracujących już pedagogów w obrębie problematyki zrównoważenia, niezależnie od tego, czy nauczyciele ci będą pracować na poziomie edukacji wczesnoszkolnej czy szkoły średniej, czy też w obszarze kształcenia technicznego i zawodowego (branżowego). Również w obrębie edukacji wyższej - i to w każdej z jej dyscyplin naukowych - powinna się pojawić problematyka dotycząca edukacji na rzecz zrównoważonego rozwoju w programach nauczania (sylabusach) i projektach badawczych;

4. Wzmacnianie i mobilizowanie młodzieży - należy angażować młode pokolenia i wykorzystywać ich potencjał, by wykazując się międzygeneracyjnym szacunkiem i czerpiąc z możliwości wzajemnego uczenia się, wspólnie brać udział w wyzwaniach zrównoważonego rozwoju;

5. Przyspieszanie wdrażania zrównoważonych rozwiązań na poziomie lokalnym - należy intensyfikować działania i podejmować współpracę z władzami terytorialnymi - miejskimi lub wiejskimi, aby budować zrównoważone społeczności lokalne (Roadmap for Implementing the Global Action Programme, 2014; Lotz-Sisitka, 2014).

Rola nauczyciela została bardzo wyraźnie wyeksponowana. Podkreślono, że realne przechodzenie od obecnego charakteru związków międzyludzkich do społeczeństw zrównoważonych będzie możliwe, gdy w pierwszej kolejności nauczyciele, zdobędą wiedzę i umiejętności oraz rozwiną odpowiednie postawy, umożliwiające zaszczepienie ideałów harmonii i zrównoważenia wśród swoich wychowanków oraz wspomagające wypracowywanie wspólnych dróg ich realizacji. Nauczyciele powinni więc być zmotywowani i zaangażowani w jak najlepsze poznanie zagadnień dotyczących zrównoważonego rozwoju, tak aby następnie, adekwatnie do wieku uczniów i charakteru swojego przedmiotu/dyscypliny naukowej, poruszać wybraną tematykę. Zapewne będzie to łatwiejsze i skuteczniejsze, gdy w trakcie przygotowania do zawodu nauczyciela, jak i podczas różnych form dokształcania i doskonalenia zawodowego, adepci i pracujący już nauczyciele zostaną wielowymiarowo przygotowani do tego zadania przez uczelnie wyższe i inne instytucje pedagogiczne (Walosik, 2013).

Takie wyzwania edukacyjne postawili przed sobą uczestnicy kolejnego światowego forum edukacyjnego - World Education Forum 2015, odbywającego się w Incheon w Korei. Najważniejsze wskazania znalazły się w dokumencie zamykającym spotkanie - Incheon Declaration. Education 2030: Towards inclusive 
and equitable quality education and lifelong learning for all (2015). Deklarację, w skrócie nazywaną Edukacja 2030, dopełnia tekst zawierający postanowienia realizacyjne, czyli Education 2030: Framework for Action (2015).

Zaproponowano w nim następujące strategie:

- zmianę polityki oświatowej i przekształcenie podstaw i programów nauczania, by promować edukację na rzecz zrównoważonego rozwoju i edukację na rzecz globalnego obywatelstwa. Należy je włączyć w główny nurt edukacji formalnej, a także realizować w edukacji poza-formalnej i nieformalnej. Potrzebne będzie więc nowe kształcenie i dokształcanie nauczycieli, a także rozwinięcie instytucji wspomagających szeroko rozumiane działania wychowawcze;

- zapewnienie wszystkim, niezależnie od płci i wieku, dostępu do edukacji poszerzającej wiedzę, rozwijającej umiejętności i kształtującej postawy, które są niezbędne, by budować pokojowo nastawione, zdrowe i zrównoważone społeczeństwa;

- rozwijanie i promocję dobrych przykładów i praktyk edukacyjnych, które zwiększają współpracę międzynarodową i ułatwiają wzajemne poznanie i zrozumienie;

- kierowanie programów z obszaru edukacji na rzecz zrównoważonego rozwoju i edukacji na rzecz globalnego obywatelstwa do osób/edukatorów, którzy następnie będą działać w swoich środowiskach lokalnych;

- budowanie przekonania, że edukacja zawdzięcza swą kluczową i wychowawczą rolę w dochodzeniu do zrównoważenia dzięki kulturze;

- wykorzystywanie i/lub tworzenie rzetelnych narzędzi ewaluacyjnych;

- promowanie kształcenia międzydyscyplinarnego, tak by treści dotyczące zrównoważenia i globalnego obywatelstwa pojawiały się na wszystkich etapach edukacyjnych i we wszystkich formach kształcenia (Education 2030: Framework for Action, 2015).

Przywołane treści dowodzą, że program dalszego kształcenia zgodnie z ideą zrównoważonego rozwoju został bardzo ambitnie nakreślony. Ma szerokie humanistyczne podstawy i dobrze wpisuje się w złożone, globalne realia oświatowe i społeczne. Widać też, że wyciągnięto wnioski z przebiegu Dekady Edukacji na rzecz Zrównoważonego Rozwoju. Dziś przed edukacją i jej głównymi realizatorami - w tym po pierwsze nauczycielami jako osobami odpowiedzialnymi za rozwój innych - stają ogromne wyzwania. 


\section{SZANSE NA IMPLEMENTACJĘ IDEI ZRÓWNOWAŻENIA W PRZYGOTOWANIU I DOSKONALENIU ZAWODOWYM POLSKICH NAUCZYCIELI}

W perspektywie wyzwań zrównoważonego rozwoju dotychczasowe koncepcje oświatowo-wychowawcze, modele szkolne, sposoby pracy z uczniem i zakres przekazywanych treści nie są już wystarczające. Na fakt ten zwracają uwagę badacze z wielu stron świata, np. z Wielkiej Brytanii (Summers, 2013), Kanady i Chin (Liu, 2009), Norwegii i Republiki Południowej Afryki (Bentham, Sinnes, Gjøtterud, 2015) czy Australii (Denby, Rickards, 2016). Zmiany na rzecz formowania człowieka zrównoważonego powinny objąć programy kształcenia zarówno na poziomie edukacji podstawowej i średniej, jak i wyższej. Oczekiwanie to dotyczy także przygotowania i doskonalenia samych nauczycieli. Dlatego, myśląc o rzeczywistym i szerokim kształceniu wychowawców, którzy będą uświadamiać swoim uczniom obecne zagrożenia (i ich potencjalne skutki) i jednocześnie uprzystępniać możliwości mierzenia się z nimi lub wspólnie poszukiwać dróg jak najlepszych w danych warunkach rozwiązań, należy dokonać znaczących zmian w przygotowaniu i doskonaleniu zawodowym nauczycieli (w treściach programowych i sposobach ich realizacji) (Moore, 2005b).

W obszarze problematyki „przekierowania” kształcenia nauczycieli pojawiają się więc m.in. następujące pytania: 1) Jaką rolę w działaniach na rzecz zrównoważenia powinny pełnić uniwersytety jako ośrodki zmiany (Lozano, Lukman, Lozano, Huisingh, Lambrecht, 2013)?; 2) Jak wprowadzać treści dotyczące zrównoważonego rozwoju do planów, siatek i programów zajęć w trakcie przygotowywania się studentów do zawodu nauczyciela (Summers, 2013; Leal Filho, 2016; Leal Filho, 2018)?; 3) Jaki jest stosunek studentów oraz wykładowców akademickich do nowych treści związanych ze zrównoważonym rozwojem (Bentham, Sinnes, Gjøtterud, 2015)?

Jak dowodzą wyniki badań, mimo że wielu studentów jest zainteresowanych uaktualnionymi treściami studiów (Denby, Rickards, 2016), to wyraźnej i szybkiej chęci zmian ze strony samych akademików nie ma. Choć stanem „naturalnym”/ normalnym powinno być życie zrównoważone, a dysproporcje i problemy należałoby traktować jako kwestie, które trzeba jak najszybciej skorygować, to opór ze strony społeczności kadry uniwersyteckiej jest zadziwiająco silny (Summers, 2013).

Obecni nauczyciele akademiccy, niezależnie od miejsca badania (np. Europa, Afryka) wykazują podobne powody i zbliżone przyczyny swojego dystansu wobec koncepcji edukacji na rzecz zrównoważenia. Przede wszystkim podkreślają: a) 
konieczność dostosowywania swej pracy do stale zmieniających się wymagań na uczelni; b) obowiązek pracy naukowej, publikowania artykułów i wspinania się po szczeblach kariery naukowej (dopiero uzyskanie tytułu doktora gwarantuje im stałość pracy); c) wymóg nieustającej samokontroli, by zawsze (niezależnie od sytuacji, w jakiej się znajdują) godnie reprezentować wartości uniwersyteckie i swój profesjonalizm; d) poczucie przepracowania z powodu zbyt dużych grup studenckich; e) oczekiwanie angażowania się w działalność organizacyjną i wspólnotową na rzecz społeczności akademickiej (Bentham, Sinnes, Gjøtterud, 2015).

Do tego dochodzi jeszcze częsty brak świadomości władz uczelni co do znaczenia edukacji na rzecz zrównoważonego rozwoju w wymiarze lokalnym i w perspektywie przyszłości całego globu. Postawa pomijania aktualnych wyzwań edukacyjnych powoduje, że wykładowcy czują się niekompetentni, by poruszać tematykę zrównoważenia, ich wiedza jest zbyt mała, a uczelnie nie organizują kursów doskonalących dla swoich pracowników. Z tego powodu wykładowcy czują, że nie mieliby się do kogo zgłosić, by uzupełnić braki w swojej wiedzy, a następnie by móc realnie przekształcać swą pracę ze studentami. Takie trudności generują u nauczycieli akademickich przekonanie o niewielkim (a nawet żadnym) związku własnej dyscypliny/wykładanych przedmiotów z problematyką zrównoważenia. Akademicy starają się też wykazać, że dominujący podział na organizacyjne formy kształcenia oraz historyczne zakresy przedmiotów uniwersyteckich nie idą w parze z problematyką edukacji na rzecz zrównoważonego rozwoju. W tej sytuacji wykładowcy wolą dostosować się do tego, co jest im już znane lub do pewnego stopnia przewidywalne, gdzie wypracowali sobie „bezpieczne” strategie poruszania się. Częściej zatem przyjmują postawę podporządkowania się wymogom administracyjno-organizacyjnym i czytelnym, „twardym”, mierzalnym kryteriom, niż dążą do twórczego angażowania się i odważnego funkcjonowania w interakcjach „miękkich”. Trudno w takich warunkach mieć nadzieję na szybką i efektywną realizację edukacji na rzecz zrównoważonego rozwoju, skoro przyszli nauczyciele nie zapoznają się jeszcze z potrzebnymi treściami (Moore, 2005a).

Wydaje mi się, że swoista „dekonstrukcja w wersji light”, czyli zmiana mająca charakter humanistycznej przebudowy edukacji wyższej, szczególnie jeśli chodzi o przyszłych i obecnych nauczycieli szkół wszystkich szczebli kształcenia, powinna stać się priorytetem w koncepcjach reformowania treści i charakteru ich toku studiów. Uczelnie powinny sprzyjać tworzeniu „przestrzeni dla pedagogicznej przemiany” (Moore, 2005b). Nie chodzi tu tylko o fizyczną przestrzeń, czyli otoczenie przyrodnicze wraz z infrastrukturą przyjazną człowiekowi (Chang, 2007), ale także o zmianę form kształcenia, tak by student/studiujący nauczyciel, a także wykładowca mieli więcej czasu i możliwości na refleksję, dialog i wspólne 
działanie. Stawianie pytań, poszukiwanie odpowiedzi, doświadczanie złożonych sytuacji, odkrywanie sensu i znaczeń wybranych kwestii, podejmowanie dyskursu akademickiego, twórcze spieranie się i dochodzenie do satysfakcjonujących rozwiązań to elementy nowej koncepcji studiowania (w tym nowych form i metod pracy) i wzrastania studenta w swym zrównoważonym człowieczeństwie.

\section{KSZTAŁCENIE STUDENTÓW UNIWERSYTETU ŁÓDZKIEGO - PRZYSZŁYCH NAUCZYCIELI CHEMII W OBSZARZE ZRÓWNOWAŻONEGO ROZWOJU. REALIZACJA PROJEKTU $X$}

Przywołane rozważania i przedstawione meandry, którymi - jak na razie - mozolnie podąża koncepcja edukacji na rzecz zrównoważonego rozwoju unaoczniają potrzebę, a nawet konieczność przechodzenia od ujęć teoretycznych do praktyki edukacji wyższej i codzienności oświatowej (Journal of Teacher Education for Sustainability; Discourse and Communication for Sustainable Education). Dlatego rzetelne, $\mathrm{tj}$. wieloaspektowe i głębokie przygotowanie nauczycieli akademickich i szkolnych do realizacji kształcenia i wychowania na rzecz zrównoważenia powinno stać się imperatywem teraźniejszej edukacji zawodowej (przed-zawodowej i doskonalącej obecnych nauczycieli) w perspektywie przyszłości. Zgadzając się z koncepcją odradzania i harmonizowania niezrównoważonych wymiarów życia człowieka, nauczyciele akademiccy i szkolni powinni umieć i chcieć postrzegać „swój” przedmiot w relacji do innych obszarów wiedzy i problemów (Wołoszyn, 1980). Inaczej mówiąc, własna przestrzeń zainteresowań i dociekań powinna być rozumiana jako fragment dopełniającej się holistycznej rzeczywistości. Stąd w rozwoju pedagogów ważne jest (samo)kształtowanie umiejętności dostrzegania lub budowania, a następnie eksponowania i wzmacniania relacji między zagadnieniami „najbliższymi”/specjalnościowymi a problematyką reprezentującą inne obszary badawcze. Taka praktyka edukacyjna każdorazowo wymaga od prowadzącego postawy zaangażowanej, myślenia i działania komplementarnego i twórczego. Postulat ten interpretuję jako aktywność, która oczekuje od nauczyciela łączenia rozumu z emocjami i twórczą wyobraźnią. Proponowana kompilacja chroni współczesnego pedagoga przed stawaniem się jednostką jednowymiarową, wąsko „sformatowaną” i w efekcie - „odczłowieczoną” (Nowakowska-Siuta, 2015). Zrównoważony rozwój potrzebuje ludzi ukształtowanych interdyscyplinarnie, wykazujących się szerokimi horyzontami myślowymi, odwagą w proponowaniu nowych rozwiązań, a także optymistycznym stosunkiem do pracy nad zmianami dla dobra człowieka i innych istot żyjących oraz świata nieożywionego. 
Stąd tak ważne jest, aby nauczyciele byli osobiście/wewnętrznie przekonani o randze i wartości treści, w które wprowadzają swoich wychowanków. Pasja przekazu jest tak samo istotna, co pasja odkrywania i tworzenia (Śliwerski, 2017a) ${ }^{5}$. A zatem racjonalność pedagogicznej pracy z uczniami - którą interpretuję jako racjonalność humanistyczną (hermeneutyczną i emancypacyjną) (Kwaśnica, 2007; Habermas, 2015), a nie „wydajnościową”, produkcyjną i nastawioną na zysk i dominację (Baker, 2005), racjonalność konstruktywistyczną versus ekologiczną (Smith, 2013) - powinna realizować następujące funkcje:

- ustanawiać „,widzialność” kształcenia i wychowania, wyznaczać horyzont poznawania tego procesu;

- przesądzając o tym, jak pytamy o kształcenie i wychowanie, określać zarazem schemat możliwych na nie odpowiedzi oraz kryteria ich ważności;

- wyznaczać ramy ludzkiego świata oraz sposób nadawania sensu znajdującym się w nim obiektom;

- umożliwiać nabywanie nowych doświadczeń, dzięki czemu mogą zachodzić zmiany w hierarchii wartości człowieka, sposobach opisu rzeczywistości, a w rezultacie zmianę samej siebie (Śliwerski, 2015b, s. 112).

Spełnienie powyższych kategorii w perspektywie edukacji na rzecz zrównoważonego rozwoju jest nie tylko niezbędną odpowiedzią wychowawcy na wyzwania współczesności, ale daje szanse na to, by nauczyciel w „świeży” sposób spojrzał na „swój” przedmiot. Postrzeganie go właśnie w innym świetle, w odmienionej perspektywie, to odkrywanie treści tegoż przedmiotu na nowo. Nadawanie im zaktualizowanego sensu i dostrzeganie związków, które uzasadniają lub nadają większą moc jego istnieniu w strukturze innych przedmiotów szkolnych, motywuje nauczyciela do rzeczywistego zaangażowania się w twórczą i szczerą

5 Dla kontrastu warto przywołać niezwykle trafne spostrzeżenie Bogusława Śliwerskiego, który stwierdza, że „dla instytucji edukacyjnej, która buduje swoje funkcje i zadania na wymogach maksymalnej wydajności, osiągania maksymalnego rezultatu przy minimalnym zużyciu zasobów i redukowaniu efektywności pracy nauczycieli oraz ich uczniów do wskaźników czysto ilościowych, charakterystyczne jest usuwanie elementów twórczych, gdyż wprowadzają one element ryzyka i niepewności oraz nie poddają się zrutynizowanemu i biurokratycznemu myśleniu. Zarządzający takim systemem starają się jak najmocniej ograniczać indywidualizm, twórczość, alternatywne rozwiązania i jakościowe mierniki kształcenia, gdyż pragną biurokratycznie kontrolować jakość wewnątrzszkolnego życia, lękając się jego spontaniczności i autonomii. Takie podejście wytwarza nudę i bierność, pozbawia zdobywanie wiedzy i umiejętności emocjonalnego związku z nimi, a całkowitym milczeniem pomija ludzki stres, niepokój, upokorzenie czy utratę nadziei” (2017a, s. 223-224). 
pracę z uczniem. Nauczyciel pasjonat to także osoba o bogatej, ale jednocześnie odpowiedzialnej wyobraźni. Oznacza to, że wyobraźnia pedagogiczna musi być zarazem wyobraźnią moralną (Górniewicz, 2001).

Nie ma wątpliwości, że odwoływanie się do wyobraźni nauczycieli, kształtowanie jej, pogłębianie i „oswobadzanie z kajdan” codzienności i typowości jest jednym z zasadniczych wyzwań związanych z edukacją na rzecz zrównoważonego rozwoju (Byrnes, 2007). Bowiem, jak konstatuje J. Górniewicz, „wyobraźnię innych może kształtować tylko ten, kto ma wyobraźnię, kto kieruje się nią w swoim życiu i kto odwołuje się do niej, inicjując procesy edukacyjne. Tylko nauczyciel obdarzony bogatą wyobraźnią jest w stanie wyzwolić przebogate pokłady twórczej wyobraźni swoich uczniów” (2001, s. 103). W dydaktyce ogólnej, a następnie w metodykach przedmiotowych znane są różnorodne strategie kształtowania wyobraźni ${ }^{6}$.

Zgadzam się z opiniami pedagogów, którzy uznają, że racjonalność pedagogiczna wraz z wyobraźnią pedagogiczną dobrze i intensywnie rozwijają się w środowisku, jakim jest wymiar estetyczno-artystyczny. W ten sposób zazębiające się trzy obszary potrzebnych dziś sprawności nauczycielskich (racjonalność pedagogiczna, wyobraźnia pedagogiczna i potencjał kulturowo-twórczy) budują całość, dzięki której pedagog może w sposób odpowiedzialny i ciekawy wprowadzać uczniów w tematykę własnego przedmiotu. Taka dyspozycja zawodowa wydaje mi się jednym z głównych warunków „alfabetyzacji na rzecz zrównoważenia” (ang. sustainable literacy) (Summers, 2013). Przyglądając się przywołanym przykładom, ukazującym stan zbyt małego zaangażowania uczelni wyższych na świecie w podejmowanie wyzwań zrównoważonego rozwoju, można przyjąć, że większość ludzi potrzebuje gruntownej alfabetyzacji w tym zakresie. Nie ma bowiem ani świadomości zagrożeń (nie umie odczytywać niebezpieczeństw), ani podstawowej wiedzy i bazowych umiejętności, jak się im przeciwstawiać lub jakie podejmować środki zaradcze (Stibbe, 2009; Jickling, 2017). Jest zatem bezbronna i zależna od grup/osób/instytucji, które bezkarnie mogą realizować swoje interesy (Gadamer, 1992; Kieżun, 2012; Martin, Schumann, 1999).

Starania ku powszechnej „alfabetyzacji na rzecz zrównoważenia” należy więc jak najszybciej podjąć w edukacji powszechnej i masowej. Wśród zaleceń bezpośrednio związanych z procesem przygotowania przyszłych nauczycieli oraz z dokształcaniem/doskonaleniem zawodowym tych już pracujących znajduje

6 Myślę tu zarówno o technikach zapamiętywania (mnemotechnikach), jak Pałac pamięci, jak i o kreśleniu map poznawczych czy komponowaniu utworu muzycznego. 
się jedno, do którego bezpośrednio odnoszę się w pracy dydaktycznej z moimi studentami. Brzmi ono następująco (zalecenie 3C.5):

Oczekiwanie, że studenci - przyszli nauczyciele analizują obowiązującą podstawę programową/program kształcenia, która będzie podstawą ich pracy w szkole, by określić zagadnienia i tematy nawiązujące do problematyki zrównoważonego rozwoju i korespondujące z lokalnymi wyzwaniami dotyczącymi zrównoważenia (Guidelines and Recommendations for Reorienting Teacher Education to Address Sustainability, 2005, s. 43-44).

Aprobując powyższe zalecenie, od kilku lat realizuję z wybranymi grupami studentów (wydziałów Uniwersytetu Łódzkiego, które prowadzą specjalność nauczycielską) ćwiczenie, wpisujące się w edukację na rzecz zrównoważonego rozwoju i jednocześnie w trzeci priorytet Globalnego Programu Działań, czyli Rozwijanie potencjału nauczycieli i edukatorów. Efektem wspólnego namysłu nad wybranymi zagadnieniami/treściami wyszczególnionymi w podstawie programowej (Rozporządzenie Ministra Edukacji Narodowej, 2012; Rozporządzenie Ministra Edukacji Narodowej, 2014; Rozporządzenie Ministra Edukacji Narodowej, 2017) jest realizacja zadania, które określam jako Karta pracy nauczyciela - Projekt $X$. Pomysł na takie ćwiczenie zrodził się z inspiracji materiałami szkoleniowymi dla nauczycieli publikowanymi przez UNESCO (Education for Sustainable Development. Toolkit, 2006; Education for Sustainable Development. Sourcebook, 2012).

Realizując przywoływane tu ćwiczenie studenci z założenia pracują w grupach. Każdy zespół ma za zadanie: a) przeanalizować treść podstawy programowej dotyczącej „własnego” przedmiotu na odpowiednim etapie kształcenia; b) wstępnie zaproponować obszar tematyczny, którego będzie dotyczyć ich propozycja zajęć (cyklu lekcji); c) przeanalizować treści z podstawy programowej do innych przedmiotów, do których powinno się nawiązać w trakcie realizacji swoich zajęć; d) odwołać się wiedzy uprzedniej członków zespołu i określić źródła/materiały umożlwiające pogłębienie tej wiedzy; e) sformułować ostateczny temat/tytuł zajęć; f) przystąpić do uzupełniania własnymi treściami formularza Projektu X. Zespół studencki ma za zadanie „przejść” przez wszystkie cztery wymiary koncepcji zrównoważonego rozwoju, czyli przez Społeczeństwo, Kulturę, Środowisko naturalne/Przyrodę i Gospodarkę/Ekonomię. Studenci, pracując w grupie, rozwijają swoje umiejętności zespołowe, wzajemnie się słuchają, inspirują i przekonują do własnych racji. Zaproponowany w formularzu porządek ma także sprzyjać racjonalnemu myśleniu, pobudzać wyobraźnię pedagogiczną studentów i jednocześnie 
mobilizować do pracy projektowej, zakładającej dojście do celów dających się określić w kategoriach estetycznych i wychowawczo/etycznie oczekiwanych z perspektywy zrównoważonego rozwoju. Projekt $X$ ma rozwijać u przyszłych nauczycieli mechanizmy samokontroli i samokształcenia, tak by obecni studenci rzeczywiście stawali się nauczycielami twórczymi, czyli osiągali najwyższy poziom swojego rozwoju zawodowego.

Egzemplifikacją możliwości odwołania się do problematyki zrównoważonego rozwoju w połączeniu ze szkolnymi treściami nauczania są prace zrealizowane przez studentów Wydziału Chemii, specjalności nauczycielskiej, Uniwersytetu Łódzkiego. Niektóre z tematów przez nich zaproponowane to: a) CSI - kryminalne zagadki w laboratorium Sherlocka Holmesa; b) Ile jedzenia jest w jedzeniu, czyli o nowoczesnej żywności; c) Jak powstaje ciasto babuni, czyli o substancjach w żywności i procesach zachodzących podczas gotowania; d) Skład chemiczny pigmentów w malarstwie olejnym; e) Chemia w dziejach historii; f) Przemiany jądrowe - chemiczna eureka czy destrukcyjna technologia?

Jako przykład namysłu studentów nad ostatnim z tematów (opracowanym jako cykl lekcji dla II klasy liceum ogólnokształcącego) przytaczam „rozpisany” jeden z filarów zrównoważonego rozwoju, czyli Społeczeństwo.

I. Społeczeństwo. 1) Wiedza - Na moim przedmiocie już realizuję: opis II Wojny Światowej oraz stanu Zimnej Wojny - okoliczności użycia broni jądrowej przez Amerykę; Chciałbym jeszcze dodać: zdobycie przez uczniów wiedzy dotyczącej militarnych i politycznych uwarunkowań powyższych konfliktów, opis przyczyn użycia tak niszczycielskiej technologii, jak broń jądrowa; 2) Umiejętności - Na moim przedmiocie już realizuję: wskazywanie przez uczniów przełomowych wydarzeń, mających wpływ na pogłębianie się konfliktów między narodami; Chciałbym jeszcze dodać: umiejętność dostrzegania przez uczniów różnych relacji społecznych w obliczu konfliktów, np. na tle politycznym; 3) Wartości/postawy - Na moim przedmiocie już realizuję: uczniowie mają świadomość nieuchronności konfliktów i dążeń do ich siłowego rozwiązywania, np. przez użycie broni jądrowej; uczniowie potrafią wskazać inne, nieagresywne sposoby rozwiązywania sporów, np. przez dyskusję, dialog; Chciałbym jeszcze dodać: kształtowanie postawy tożsamości, świadomości obywatelskiej i społecznej w okresach trudnych dla całej społeczności, np. w trakcie wojny; 4) Lokalne propozycje - Na moim przedmiocie już realizuję: spotkania pozalekcyjne na świetlicy dotyczące rozwiązywania sytuacji konfliktowych oraz kształtowania postaw obywatelskich i patriotycznych; Chciałbym jeszcze dodać: prowadzenie fikcyjnych rozpraw sądowych, które będą dotyczyć 
rozwiązywania konfliktów pomiędzy klasami; 5) Perspektywy - Na moim przedmiocie już realizuję: racjonalne podejście uczniów do konfliktów społecznych, w których mogą się znaleźć w swoim dalszym życiu (zdolność komunikacji w różnych środowiskach, wykazywanie postawy tolerancji, rozumienie różnych punktów widzenia); Chciałbym jeszcze dodać: radzenie sobie ze stanami frustracji spowodowanymi różnymi sytuacjami w dorosłym życiu.

Całościowa analiza zebranego materiału potwierdziła, że studenci bardzo rzetelnie i kreatywnie podeszli do zadania. Praca, potraktowana jako ćwiczenie sprawdzające możliwości szerszego i zarazem osadzonego w czterech obszarach-filarach funkcjonowania człowieka, spojrzenia na „swój” przedmiot szkolny, wypadła bardzo dobrze. Co ważne, treści w nim zawarte wyraźnie nawiązują do treści innych przedmiotów szkolnych, jak Język polski, Historia, Wiedza o społeczeństwie, Wiedza o kulturze, Fizyka i Geografia. Projekt $X$ jest więc nie tylko sposobem kształcenia nauczyciela ku zrównoważeniu, ale jest też jednym z narzędzi budowania współpracy wewnątrzszkolnej, tworzenia partnerskiej sieci między nauczycielami i drogą osiągania rzeczywistej korelacji międzyprzedmiotowej.

\section{ZAKOŃCZENIE}

Etos edukacji na rzecz zrównoważonego rozwoju, jak podkreślono w Globalnym Programie Działań (przeznaczonym do realizacji do 2030 r.), staje się coraz bardziej znany, rozpoznawalny i pożądany. Jednak w obliczu dominujących i w dalszym ciągu silnych mainstreamowych tendencji do funkcjonowania według wzorca niezrównoważonego koncepcja kształcenia i wychowania człowieka pragnącego żyć w harmonii ze sobą i innymi istotami, a także z nieożywionymi dobrami naszej planety jest bardzo trudna do spełnienia.

Neoliberalny i odhumanizowany świat, w którym zrelatywizowały się wszelkie zależności między człowiekiem a jego środowiskami, normy, światopoglądy, sposoby zachowań i możliwości (a właściwie niemożność) dokonywania jednoznacznych ocen określonych faktów i sytuacji, doprowadził do stanu całkowitego rozchwiania i słabości jednostek. Migotliwość obrazów i pulsowanie znaczeń sprawiły, że sam człowiek stał się również „chwilowy” i impulsywny, a jego decyzje - ulotne, gdyż wynikające z bezpośrednich sytuacji i bodźców.

Sprzeciw wobec tendencji do takiego ,urabiania” jednostek wyraża się w pytaniach o charakter i jakość współczesnego kształcenia z wychyleniem ku przyszłości. Z perspektywy zrównoważonego rozwoju humanistyczne i wielowymiarowe 
wzrastanie człowieka jest zasadniczym fundamentem przywracania mu prawa do istnienia w harmonii i równowadze z innymi elementami środowisk, w których żyje i które powinien współtworzyć. Czytelna zmiana modeli wychowania z generujących rywalizujące ze sobą osobniki na rzecz paradygmatu wzajemności, współpracy i współodpowiedzialności (Nikitorowicz, 2018) - wymaga odpowiednio przygotowanych nauczycieli. Nieustająco aktualnym pozostaje więc pytanie Zenona Jasińskiego o to, „jak i jaki typ nauczyciela powinniśmy przygotować” (Jasiński, 2006, s. 33), gdyż w dalszym ciągu jest ono „nierozstrzygnięte i otwarte do publicznej debaty” (2006, s. 33). Dekada Edukacji na rzecz Zrównoważonego Rozwoju rozpoczęła ruch ku zmianie. Pojawiło się wiele inicjatyw oddolnych wskazujących, że wśród nauczycieli są już tacy, którym zależy na naprawie tego, co w życiu człowieka i w jego otoczeniu zostało niemalże zniszczone, kompletnie zdeformowane lub niepokojąco strywializowane i uprzedmiotowione przez narrację nowej swobody i nieustającej wolności.

Postuluje się więc, by zreformować edukację nauczycieli adekwatnie do wzywań i zagrożeń XXI w. (Propozycja nowego modelu kształcenia przyszłych nauczycieli, 2018) ${ }^{7}$. Nie jest to jednak łatwe z wielu powodów. Jednym z nich są wysokie koszty dogłębnych i całościowo przeprowadzanych zmian w oświacie. Dlatego też kształcenie i doskonalenie zawodowe kadry pedagogicznej zgodne z potrzebami zrównoważonego rozwoju wymagać będzie znacznych nakładów finansowych. Dziś jednak wydaje się, że głównym problemem jest konieczność powszechnego i wielotorowego uprzystępniania nauczycielom i kandydatom na nauczycieli samej problematyki i wyzwań zrównoważonego rozwoju. Na nich bowiem spoczywa zadanie szerokiej alfabetyzacji społeczeństwa na rzecz zrównoważenia. Dlatego już drugą dekadę XXI w. w wymiarze ogólnoświatowym poszukuje się innowacyjnych metod kształcenia i wypracowuje się strategie nauczania, które byłyby jak najbardziej adekwatne do tak zakreślonych wyzwań edukacyjnych (Bałachowicz, 2017; Down, 2007; Lotz-Sisitka, Schudel, O’Donoghue, Irwin, 2007). Jednym z podejść dydaktycznych rozwijających kompetencje przyszłych nauczycieli jest zaproponowana przeze mnie metoda (a nawet strategia), którą nazwałam Projektem X. Jej źródła tkwią w koncepcjach metodycznych promowanych przez UNESCO w czasie trwania Dekady Edukacji na rzecz Zrównoważonego Rozwoju.

7 Niestety w najnowszej propozycji MNiSW dotyczącej przygotowania polskich nauczycieli do pracy w aktualnej rzeczywistości i przygotowania uczniów do współtworzenia dobrej przyszłości zupełnie nie dostrzeżono wagi i znaczenia kształcenia nauczycieli na rzecz zrównoważenia. W mojej ocenie propozycja ta wymaga więc jak najszybszych korekt. 
Kilkuletnia praca z kandydatami na nauczycieli szkolnych (przedmiotów ścisłych i humanistycznych) wskazuje na wartość samego narzędzia (arkusza do realizacji Projektu $X$ ), a także na sensowność stasowania tej strategii we wprowadzaniu studentów w problematykę zrównoważenia. W młodych ludziach tkwi ogromny potencjał twórczy, a także chęć i otwartość do podejmowania wyzwań. Wewnętrzna motywacja i zapał do tworzenia uaktywniają się, gdy prezentowane problemy stają się dla nich zrozumiałe i sensowne. Tym samym, uzasadniają potrzebę kreatywnego angażowania się w pracę nad zadaniami i wchodzenia w obszary nowe i dotychczas przez nauczycieli nie spenetrowane. Zachęcają do nowatorskiego odczytywania treści przedmiotowych i szukania między nimi powiązań, budowania sieci zależności z różnych obszarów wiedzy (przedmiotów) i wreszcie - dochodzenia do całościowych ujęć. Taka wieloaspektowa i wielowątkowa aktywność buduje u pedagogów system wartości i uświadamia postawy, które warto wprowadzać w czyn, dążąc do (samo)wychowania człowieka zrównoważonego, umiejącego i chcącego tworzyć wspólny i przyjazny dla wszystkich istnień świat. W ten sposób edukacja na rzecz zrównoważonego rozwoju staje się pedagogiką nadziei i odwagi, która, w interpretacji Bogusława Śliwerskiego:

(...) kierując się w stronę przyszłości - otwiera nowe perspektywy dla własnego istnienia i rozwoju. Jest przy tym pełna optymizmu i zaraża nim każdego, kto jest nią zainteresowany. To pedagogika bliższa utopii, sile promieniującego z jej wnętrza optymizmu, żaru, pociechy, zawierzenia, pasji i zaangażowania. Tak rozumiana pedagogika jest nośnikiem wiary, fascynacji, dążenia do upragnionych celów, jest pedagogiką transformacji, odmiany, siły oporu transformatywnego (Śliwerski, 2017b, s. 15).

\section{Bibliografia}

Aichi-Nagoya Declaration on Education for Sustainable Development (2015). Pobrane z: http://www.unesco.org/new/fileadmin/MULTIMEDIA/HQ/ERI/pdf/Aichi-Nagoya_Declaration_EN.pdf.

Baker, Ch. (2005). Studia kulturowe. Teoria i praktyka, przekł. Agata Sadza. Kraków: Wydawnictwo Uniwersytetu Jagiellońskiego.

Bałachowicz, J. (2017). Idea zrównoważonego rozwoju w edukacji dziecka. Prima Educatione, 1, 21-38. DOI: 10.17951/PE/2017/1.21.

Bentham, H., Sinnes, A., Gjøtterud, S. (2015). A Teacher Education for Sustainable Development System: An Institutional Responsibility. International Journal of Higher Education, 4 (4), 158-177. Pobrane z: https://doi.org/10.5430/ijhe.v4n4p158.

Byrnes, L. (2007). Swiss International Teachers' Program. W: Ch. Hopkins, R. McKeown 
(eds.), Good Practices in Teacher Education Institutions (s. 11-16). Paris: UNESCO, Section of Education for Sustainable Development.

Chang, T. (2007). Sustainable Campus Initiative. W: Ch. Hopkins, R. McKeown (eds.), Good Practices in Teacher Education Institutions (s. 35-40). Paris: UNESCO, Section of Education for Sustainable Development.

Denby, L., Rickards, S. (2016). An Approach to Embedding Sustainability into Undergraduate Curriculum: Macquarie University, Australia Case Study. W: W. Leal Filho, P. Pace (eds.), Teaching Education for Sustainable Development at University Level (s. 9-33). Switzerland: Springer International Publishing, World Sustainability Series.

Discourse and Communication for Sustainable Education. The Journal of UNESCO Chair on the Interplay of Tradition and Innovation in Education for Sustainable Development (ESD) at Daugavpils University, Latvia, e-ISSN: 2255-7547. Pobrano z: http://ise-lv. eu/publications.php?show=39\&pub=13.

Down, L. (2007). Literature to Address the Problem of Violence: Infusing ESD in the Curriculum. W: Ch. Hopkins, R. McKeown (eds.), Good Practices in Teacher Education Institutions (s. 7-10). Paris: UNESCO, Section of Education for Sustainable Development.

Friesen, N. (2018). Personalized Learning Technology and the New Behaviorism: Beyond Freedom and Dignity. Pobrane z: http://www.academia.edu/Documents/in/ Learning_Analytics.

Gadamer, H.G. (1992). Dziedzictwo Europy, przekł. Andrzej Przyłębski. Warszawa: Fundacja Aletheia.

General Assembly, A/RES/69/211 (2015). Follow-up to the United Nations Decade of Education for Sustainable Development (2005-2014): Global Action Programme on Education for Sustainable Development. Pobrane z: http://www.unesco.at/bildung/ gap_res_n1471200.pdf.

Górniewicz, J. (2001). Kategorie pedagogiczne. Odpowiedzialność, podmiotowość, samorealizacja, tolerancja, twórczość, wyobraźnia. Olsztyn: Wydawnictwo Uniwersytetu Warmińsko-Mazurskiego.

Habermas, J. (2015). Przyczynek do krytyki rozumu funkcjonalnego, przekł. Andrzej Maciej Kaniowski, Marek J. Siemek. Warszawa: Wydawnictwo Naukowe PWN.

ICSU \& ISSC (2015). Review of Targets for the Sustainable Development Goals: The Science Perspective. Pobrane z: http://www.icsu.org/publications/reports-and-reviews/ review-of-targets-for-the-sustainable-development-goals-the-science-perspective-2015/ SDG-Report.pdf.

Jasiński, Z. (2006). A word about programs and standards of educating teachers and pedagogues in Poland. W: Z. Jasiński, T. Lewowicki (red.), Education for Teachers and Pedagogues: Issues in International Context. Opole: Uniwersytet Opolski.

Jickling, B., Sterling, S. (eds.) (2017). Post-sustainability and Environmental Education. Remaking Education for the Future. Cham, Switzerland: Palgrave Macmillan Journal of Teacher Education for Sustainability. The Journal of UNESCO Chair on the Interplay of Tradition and Innovation in Education for Sustainable Development (ESD) at Daugavpils University, Latvia, ISSN: 1691-4147, e-ISSN 1691-5534. Pobrano z: http://www.ise-lv.eu/publications.php?\&pub=3\&tid=3. 
Karta Ziemi. Pobrano z: https://artaziemi.wordpress.com/tekst-karty-2.

Kieżun, W. (2012). Patologia transformacji. Warszawa: Wydawnictwo Poltex.

Klichowski, M. (2014). Narodziny cyborgizacji. Poznań: Wydawnictwo Naukowe UAM.

Kwaśnica, R. (2007). Dwie racjonalności. Od filozofii sensu ku pedagogice ogólnej. Wrocław: Wydawnictwo Naukowe Dolnośląskiej Szkoły Wyższej TPW.

Leal Filho, W., Pace, P. (eds.) (2016). Teaching Education for Sustainable Development at University Level. Switzerland: Springer International Publishing, World Sustainability Series.

Leal Filho, W. (ed.) (2018). Implementing Sustainability in the Curriculum of Universities. Approaches, Methods, and Projects. Switzerland: Springer International Publishing, World Sustainability Series.

Liu, J. (2009). Education for Sustainable Development in Teacher Education: Issues in the Case of York University in Canada. Asian Social Science, 5 (5), 46-49. Pobrane z: http://www.ccsenet.org/journal/index.php/ass/article/viewFile/1700/1600.

Lotz-Sisitka, H., Schudel, I., O’Donoghue, R., Irwin, P. (2007). Schools and Sustainability in South Africa: Piloting a Reflexive Model for Accredited In-service Teacher Education. W: Ch. Hopkins, R. McKeown (eds.), Good Practices in Teacher Education Institutions (s. 47-54). Paris: UNESCO, Section of Education for Sustainable Development.

Lotz-Sisitka, H. (2015). UNESCO World Conference on Education for Sustainable Development Conference Report. Pobrano z: http://unesdoc.unesco.org/images/0023/002328/232888E.pdf.

Lozano, R., Lukman, R., Lozano, F.J., Huisingh, D., Lambrecht, W. (2013). Declarations for Sustainability in Higher Education: Becoming Better Leaders Through Addressing the University System. Journal of Cleaner Production, 48, 10-19. Pobrano z: https:// doi.org/10.1016/j.jclepro.2011.10.006.

Martel, F. (2011). Mainstream. Co podoba się wszędzie na świecie, przekł. Karolina Sikorska. Warszawa: Wydawnictwo Czarna Owca.

Martin, H.P., Schumann, H. (1999). Pułapka globalizacji. Atak na demokrację i dobrobyt, przekł. M. Zybura. Wrocław: Wydawnictwo Dolnośląskie.

Mayor, F., Bind, J. (2001). Przyszłość świata, przekł. J. Wolf, A. Janik, W. Rabczuk. Warszawa: Fundacja Studów i Badań Edukacyjnych.

MNiSW (2018). Propozycja nowego modelu kształcenia przyszłych nauczycieli. Pobrane z: http://www.nauka.gov.pl/g2/oryginal/2018_03/6cf639c7f57d9166a000ee046cb0cd61.pdf.

Moore, J. (2005a). Barriers and Pathways to Creating Sustainability Education Programs: Policy, Rhetoric and Reality. Environmental Education Research, 11 (5), 537-555. Pobrane z: http://www3.telus.net/janetmoore/Env.Ed.Res.JM2005.pdf.

Moore, J. (2005b). Seven Recommendations for Creating Sustainability Education at the University Level. A Guide for Change Agents. International Journal of Sustainability in Higher Education, 6 (4), 326-339. Pobrane z: https://www.researchgate.net/ publication/228627903_Seven_recommendations_for_creating_sustainability_education_at_the_university_level_A_guide_for_change_agents.

Nikitorowicz, J. (2018). Etnopedagogika w kontekście wielokulturowości i ustawicznie kształtujq̨cej się tożsamości. Kraków: Oficyna Wydawnicza „Impuls”.

Nowakowska-Siuta, R. (2015). Racjonalność emancypacyjna w perspektywie porównaw- 
czej. W: R. Nowakowska-Siuta, B. Śliwerski (red.), Racjonalność procesu kształcenia. Studium z polityki oświatowej i pedagogiki porównawczej (s. 7-108). Kraków: Oficyna Wydawnicza „Impuls”.

Rogalska-Marasińska, A. (2017). Edukacja międzykulturowa na rzecz zrównoważonego rozwoju. Łódź: Wydawnictwo Uniwersytetu Łódzkiego.

Rozporządzenie Ministra Edukacji Narodowej z dnia 27 sierpnia 2012 r. w sprawie podstawy programowej wychowania przedszkolnego oraz kształcenia ogólnego w poszczególnych typach szkól. Pobrane z: http://isap.sejm.gov.pl/DetailsServlet?i$\mathrm{d}=$ WDU20120000977.

Rozporządzenie Ministra Edukacji Narodowej z dnia 30 maja 2014 r. zmieniające rozporządzenie w sprawie podstawy programowej wychowania przedszkolnego oraz kształcenia ogólnego w poszczególnych typach szkół. Pobrane z: http://isap.sejm.gov. pl/DetailsServlet?id=WDU20140000803.

Rozporządzenie Ministra Edukacji Narodowej z dnia 14 lutego 2017 r. w sprawie podstawy programowej wychowania przedszkolnego oraz podstawy programowej kształcenia ogólnego dla szkoły podstawowej, w tym dla uczniów z niepełnosprawnością intelektualną w stopniu umiarkowanym lub znacznym, kształcenia ogólnego dla branżowej szkoły I stopnia, kształcenia ogólnego dla szkoły specjalnej przysposabiające do pracy oraz kształcenia ogólnego dla szkoły policealnej. Pobrane z: http://prawo.sejm.gov.pl/ isap.nsf/DocDetails.xsp?id=WDU20170000356.

Smith, V.L. (2013). Racjonalność w ekonomii, przekł. Marek Dąbrowski, Mirosław Raczyński, Rafał Morawczyński. Warszawa: Wolters Kluwer Polska SA.

Stibbe, A. (ed.) (2009). A Handbook of Sustainability Literacy. Skills for a Changing World. Darlington, UK: Green Books Ltd. Pobrane z: http://arts.brighton.ac.uk/stibbe-handbook-of-sustainability.

Summers, D. (2013). Education for Sustainable Development in Initial Teacher Education: From Compliance to Commitment - Sowing the Seeds of Change. Journal of Education for Sustainable Development, 7 (2), 205-222. Pobrane z: http://journals.sagepub.com/ doi/pdf/10.1177/0973408214526490.

Śliwerski, B. (2015a). Edukacja (w) polityce. Polityka (w) edukacji. Kraków: Oficyna Wydawnicza „Impuls”.

Śliwerski, B. (2015b). Racjonalność pedagogiczna polskiej polityki oświatowej w latach 1989-2014. W: R. Nowakowska-Siuta, B. Śliwerski (red.), Racjonalność procesu kształcenia. Studium z polityki oświatowej i pedagogiki porównawczej (s. 109-252). Kraków: Oficyna Wydawnicza „Impuls”.

Śliwerski, B. (2017a). Meblowanie szkolnej demokracji. Warszawa: Wolters Kluwer Polska SA.

B. Śliwerski, B. (2017b). Pedagogika nadziei. Prima Educatione, 1, 13-19. DOI: 10.17951/ PE/2017.1.13.

UNESCO (2005). Guidelines and Recommendations for Reorienting Teacher Education to Address Sustainability. United Nations Decade of Education for Sustainable Development (2005-2014). France: UNESCO Education for Sustainable Development in Action, Technical Paper No. 2. Pobrane z: http://unesdoc.unesco.org/images/0014/001433/143370E.pdf. 
UNESCO (2006). Education for Sustainable Development. Toolkit. Learning and Training Tools No 1. France: UNESCO, United Nations Decade of Education for Sustainable Development (2005-2014). Pobrane z: http://unesdoc.unesco.org/images/0015/001524/152453eo.pdf.

UNESCO (2012). Education for Sustainable Development. Sourcebook. Learning and Training Tools No 4. France: UNESCO, Education for Sustainable Development in Action. Pobrane z: http://unesdoc.unesco.org/images/0021/002163/216383e.pdf.

UNESCO General Conference, 37th Session, Paris (2013). Proposal for a Global Action Programme on Education for Sustainable Development as Follow-up to the United Nations Decade of Education for Sustainable Development (DESD) After 2014. Pobrane z: http://unesdoc.unesco.org/images/0022/002243/224368e.pdf.

UNESCO (2014). Shaping the future we want, UN Decade of Education for Sustainable Development (2005-2014), FINAL REPORT. DESD Monitoring and Evaluation. Pobrane z: http://www.unesco.pl/fileadmin/user_upload/pdf/Koncowy_Raport_DESD_ The_Future_we_Want.pdf.

UNESCO (2014). UNESCO Roadmap for Implementing the Global Action Programme on Education for Sustainable Development. Pobrane z: http://unesdoc.unesco.org/ images/0023/002305/230514e.pdf.

UN (2015). Review of the implementation of the United Nations Decade of Education for Sustainable Development, 2005-2014. Pobrane z: https://documents-dds-ny.un.org/ doc/UNDOC/GEN/N15/240/07/pdf/N1524007.pdf?OpenElement.

UNESCO together with UNICEF, the World Bank, UNFPA, UNDP, UN Women and UNHCR (2015). Education 2030: Incheon Declaration. Towards inclusive and equitable quality education and lifelong learning for all. Pobrane $\mathrm{z}$ : http://unesdoc.unesco. org/images/0023/002338/233813M.pdf.

UNESCO (2015). Education 2030: Incheon Declaration and Framework for Action. Towards inclusive and equitable quality education and lifelong learning for all. Pobrane z: http://www.uis.unesco.org/Education/Documents/incheon-framework-for-action-en. pdf.

Walosik, A. (2013). Przez edukację do zrównoważonego rozwoju. Kraków: Wydawnictwo Naukowe Uniwersytetu Pedagogicznego.

Wołoszyn, S. (1980). Współczesne tendencje w kształceniu nauczycieli. Profil nauczyciela jutra. W: B. Suchodolski (red.), Pedagogika. Podręcznik dla kandydatów na nauczycieli (s. 746-765). Warszawa: Państwowe Wydawnictwo Naukowe. 